\title{
ANALYSIS \\ Improving poisoning diagnosis and surveillance of street pesticides
}

\author{
Hanna-Andrea Rother
}

An effective surveillance system is required to reduce pesticide exposures and poisonings, especially from street pesticides (illegal, unlabelled, and decanted agricultural pesticides used predominately for urban household purposes). Poisoning from any pesticide class, not only organophosphates, constitutes a medically notifiable condition in South Africa. Current practice, however, is to report only organophosphate cases, resulting in severe under-reporting. The lack of data concerning the link between poisonings and street pesticides has led to the mistaken assumption that urban populations are not at risk from significant pesticide exposures and poisonings. Without accurate statistics, healthcare professionals and policy makers are unaware of the contribution of street pesticide poisonings to the overall health burden. Accurate diagnosis is a prerequisite for notification and subsequent surveillance. An algorithm has been developed to enable healthcare professionals to improve the diagnosis and notification of pesticide poisonings.

S Afr Med J 2012;102(6):485-488.
Pesticide poisoning constitutes a notifiable medical condition in South Africa (SA) (National Health Act 61, 2003; referred to as 'poisoning agricultural stock remedies'). ${ }^{1}$ Legislation requires the notification of poisoning from any pesticide registered under Act 36 of 1947 to the national Department of Health (DoH). Despite this, current practice is to report only those resulting from organophosphate-containing pesticides (OPs). Failure to report poisonings from other pesticides - such as carbamates, pyrethroids, organochlorines and coumarin rodenticides - violates legislation and results in gross under-reporting, ${ }^{2}$ leading to flawed national statistics and limited government commitment to mitigate the problem.

Extensive pesticide use and exposure in SA (Table 1) increases the potential for a high burden of poisoning and long-term health effects. These factors remain a low public health priority, however, as a result of difficulties in estimating overall burden. ${ }^{3}$ Two problem areas, in relation to surveillance data, are the non- and misdiagnosis of poisoning cases. ${ }^{4}$ Non-diagnosis results from the assumption that poisoning symptoms are due to some other cause (disease, illness or exposure). Even in the recognition of poisoning, the class of pesticide may be misdiagnosed (e.g. OP poisoning is assumed in the event of carbamate exposure). Both scenarios play a significant role in incorrect or non-treatment and in inadequate or non-notification.

Training in the diagnosis of and routine screening for pesticide exposure is inadequate, especially in relation to exposed urban populations and non-OP exposures. In a study of physicians in the USA, $69 \%$ had never made a pesticide poisoning diagnosis and 53\% had not considered making such a diagnosis; a further $64 \%$ believed that they lacked sufficient education to address patients' questions about pesticides. ${ }^{5}$ If pesticide exposure is not routinely considered in the diagnostic process - by conducting an environmental health history - the symptoms of patients attending urban healthcare facilities or those from non-agricultural areas may not be diagnosed adequately. ${ }^{6}$ Symptoms of fatigue, nausea, sore throat, muscle cramps, headache and stomach cramps may well be treated as 'flu, when they also typically

Dr Hanna-Andrea Rother is Head of the Health Risk Management Programme, Centre for Occupational and Environmental Health Research, School of Public Health and Family Medicine, University of Cape Town. relate to pesticide exposure. ${ }^{7}$ Incorrect diagnosis not only results in poor and ineffective treatment, but also impedes notification.

\section{Street pesticides}

Accurate notification of poisonings plays a vital role in the monitoring and control of street pesticides - inexpensive and predominantly illegal products sold in SA at train stations, informal markets and taxi ranks, and door-to-door by vendors. ${ }^{8}$ Laboratory results from samples of these pesticides reveal that the active ingredients are mainly organosphosphates (e.g. methamidophos, chlorpyrifos), pryrethroids (e.g. cypermethrin) and carbamates (e.g. aldicarb - the most acutely toxic pesticide sold). ${ }^{9}$ While registered for agricultural use under Act 36 of 1947, these acutely toxic pesticides are illegally decanted and sold in concentrated or diluted form in unlabelled containers, or as granules. These readily accessible products are effective in controlling poverty-related pests (e.g. bed bugs, cockroaches, flies, and rats) and are less expensive than registered household products. For example, unlabelled aldicarb is colloquially referred to as 'two-steps', in reference to how many steps rats and mice take before death. ${ }^{9}$

A recent study linked child poisoning cases in SA to street pesticides and indicated that the incorrect documentation in clinical case notes may result in the underestimation of the prevalence of such cases. ${ }^{10}$ The challenge for healthcare professionals is linking poisonings to products that are illegal, unlabelled and of varying formulations/concentrations. Street pesticides use occurs in many countries (e.g. the USA, Zimbabwe, Tanzania, Brazil, the Dominican Republic, Mozambique); ${ }^{9}$ therefore, there is a global need to improve identification of the extent to which these pesticides contribute to morbidity and mortality.

\section{Development of a pesticide poisoning algorithm}

We established a Pesticide Policy Reference Group with multiple stakeholders from academia and government, to advise a multifaceted project on street pesticides and child poisonings. ${ }^{8,9}$ With ethics approval from the University of Cape Town (UCT), the project entailed: (i) collecting narratives of poisoning cases at Red Cross War Memorial Children's Hospital (RCWMCH) in Cape Town, (ii) conducting reviews of poisoned children's records, (iii) interviewing informal sellers of street pesticides, (iv) analysing samples of street pesticides, and $(v)$ conducting a township-based household survey, ${ }^{8,9}$ This research revealed that healthcare professionals face problems with the diagnosis, treatment and notification of poisoning cases especially those involving street pesticides. 
Table 1. Examples of extensive pesticide use in South Africa

\begin{tabular}{|c|c|c|}
\hline Sector & Use (not exhaustive) & Comments \\
\hline Agriculture & $\begin{array}{l}\text { Crops } \\
\text { Grain storage/silos } \\
\text { Soil treatment } \\
\text { Weed control } \\
\text { Horticulture (fruit, flowers, greenhouse production) }\end{array}$ & $\begin{array}{l}\text { Large commercial and small-scale farming } \\
\text { operations }\end{array}$ \\
\hline Borders & $\begin{array}{l}\text { Mosquito control on commercial airlines } \\
\text { Control of foot-and-mouth disease } \\
\text { Phytosanitary control }\end{array}$ & $\begin{array}{l}\text { Required spraying inside planes prior to flight } \\
\text { by some destinations }\end{array}$ \\
\hline Household & $\begin{array}{l}\text { Insect control } \\
\text { Rodent control } \\
\text { Mosquito repellents } \\
\text { Lice and scabies shampoo/lotion } \\
\text { Flea/tick control on pets/animals } \\
\text { Garden plants/pests (roses, snails) } \\
\text { Fungicide-containing paints } \\
\text { Germ/microbial control (soaps, disinfectants, mouth washes)* }\end{array}$ & $\begin{array}{l}\text { Home and home garden uses by individuals and } \\
\text { commercial pest control operators }\end{array}$ \\
\hline Forestry & $\begin{array}{l}\text { Removal of alien vegetation } \\
\text { Timber treatments } \\
\text { Fungal and insect treatments }\end{array}$ & Government or municipal operations \\
\hline Leisure areas & $\begin{array}{l}\text { Public parks and gardens } \\
\text { Golf courses } \\
\text { Sports grounds } \\
\text { Hotels/resorts buildings and grounds }\end{array}$ & $\begin{array}{l}\text { Commercial pest control operators or staff of } \\
\text { company }\end{array}$ \\
\hline Laboratories & Research & Industry, government, universities \\
\hline Migratory pest control & $\begin{array}{l}\text { Quelea bird control } \\
\text { Locust control } \\
\text { Other migratory pests }\end{array}$ & By government and farmers \\
\hline Public health & $\begin{array}{l}\text { Malaria control } \\
\text { Community control of cockroaches, rats, bedbugs and other pests }\end{array}$ & Government or municipal operations \\
\hline Public places & $\begin{array}{l}\text { Schools } \\
\text { Hospitals } \\
\text { Public buildings (restaurants, shops and malls, churches) } \\
\text { Office buildings } \\
\text { Land fills } \\
\text { Weed control on roads, pavements and verges }\end{array}$ & Commercial pest control operations \\
\hline Transport & $\begin{array}{l}\text { Movement of pesticide products on land and sea } \\
\text { Fungicides on boat bottoms }\end{array}$ & Municipalities; government \\
\hline Veterinary purposes & $\begin{array}{l}\text { Livestock treatment } \\
\text { Larvicides added to chicken feed for fly control } \\
\text { Manage treatment } \\
\text { Ear treatment }\end{array}$ & \\
\hline Unregistered uses & $\begin{array}{l}\text { Street pesticides } \\
\text { Problem animal control } \\
\text { Human self-harm } \\
\text { Homicides } \\
\text { Killing fish for consumption/sale }\end{array}$ & $\begin{array}{l}\text { Agricultural pesticides decanted and sold for } \\
\text { domestic use }\end{array}$ \\
\hline
\end{tabular}

A specific concern was the identification of poisonings from exposure to unlabelled products. The review of the records of all suspected pesticide poisoning cases at RCWMCH between 2004 and 2006 ( $N=80$ ) illustrated a link between suspected poisonings and street pesticides, and highlighted the importance of the provision of enough descriptive and appropriate information by physicians to establish this link (Table 2). While accurate statistics are not available owing to inherent complexity, this study estimated that at least $50 \%$ of suspected pesticide poisoning cases were related to street pesticides.

A critical issue is the standardisation of healthcare professionals' descriptive information to improve notification of these cases. Although resources are available to support healthcare professionals in 
Table 2. Examples of case report poisoning narratives implicating street pesticides - RCWMCH 2004 - 2006

'Child was found by the aunt with presenting symptoms. His 12 -year-old cousin said that the child had drunk from a juice bottle containing cockroach poison which was kept under the bed. The poison looked like milk.

'Child was found eating flour - rat poison, unsure how much. It comes in black pellets, in unmarked plastic bags and was bought at the shop'

'Mom brought poison from someone at the station - comes in pellet form. Poison mixed with food and left for mice to eat. Child was hungry so she ate poison/food mixture.'

'Mom bought rat poison from a street vendor - black granules, unlabelled in a box. She woke up and found the child with the dish of poison in his hands with the granules in his mouth.'

'Mother found child chewing on an unopened plastic, containing rat poison. Granules. Child found eating granules out of a small hole in the packet'.

'An unknown substance for cockroaches was sprayed in the room that the child slept in. The child was treated and discharged but returned the next day with the same symptoms. She presumably slept in the same room again'.

'A flea poison that was bought on the street was used on the child's bed for bed bugs and the child slept on the sprayed sheets.'

'Granny gave $5 \mathrm{ml}$ of chlorpyrifos thinking it was cough syrup. She then notified the social worker once she realised what she had done.'

'Granny gave 1 tsp of cockroach poison to the child thinking it was flu medicine.'

'Mom accidentally gave child a teaspoon of cockroach poison. She thought that it was medicine given by hospital'.

\section{Improving notification of pesticide poisonings}

\section{IDENTIFYING TYPE OF PESTICIDE(S) INVOLVED}

The first healthcare professional to come into contact with a patient presenting with pesticide poisoning is required by law to notify the Department of Health (http://www.doh.gov.za/docs/dns-fhtml).

Notify ALL pesticide poisonings regardless of the active ingredient. Do not report ONLY organophosphate poisonings. Identify the pesticide involved and provide detailed information in the patient's file. Use the flow chart below:

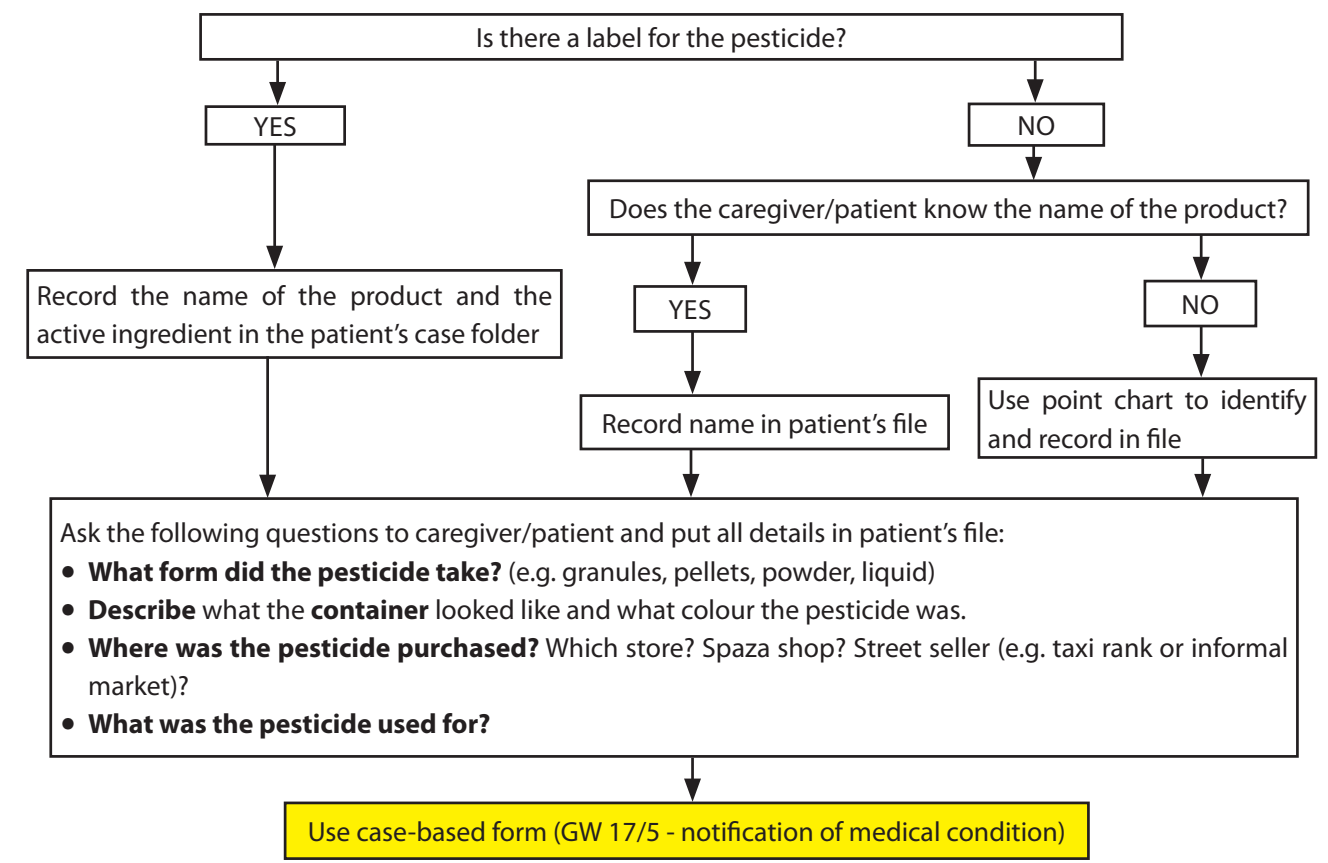

Record all information in as much detail as possible so the national Department of Health (DoH) can monitor the occurrence of pesticide poisonings, develop and implement intervention strategies and scrutinise the strategies' effectiveness

Fig. 1. Algorithm for improving the notification of pesticide poisonings. 
Table 3. Examples of pesticide active ingredients responsible for poisoning

\begin{tabular}{ll}
\hline Organophosphates & Carbamates \\
Methyl parathion & Aldicarb \\
Ethal parathion & Carbofuran \\
Malathion & Oxamyl \\
Diazinon & Methomyl \\
Fenthion & Formetanate \\
Dichlorvos & Methiocarb \\
Chlorpyrifos & Aminocarb \\
Trichlorfon & Mecarbam \\
& Bendiocarb \\
& Propoxur
\end{tabular}

\section{Anticoagulants}

Brodifacoum

Difethialone

Chlorofacinone

Coumachlor

Difenacoum

Diphacinone

Warfarin

\section{Pyrethroids}

Allethrin

Bifenthrin

Cypermeter

Permethrin

Deltamethrin

\section{Organochlorines}

Lindane (lice shampoo)

$\mathrm{N}, \mathrm{N}$-diethyl-meta-toluamide

(DEET - mosquito repellent)

identifying signs and symptoms of pesticide poisonings, no literature is available via easily accessible resources to improve notification.

The Health Risk Management Programme (HRMP) at UCT therefore developed an algorithm for 'Improving Notification of Pesticide Poisoning' (Fig. 1) (http://www.coehr.uct.ac.za/publications/ pestrel.php). The algorithm outlines the decision-making process to be followed when presented with a case of poisoning, particularly when the poison is unlabelled. To aid more accurate product (and active ingredient; Table 3) identification, it includes a point chart to enable caregivers/patients to point out the product (or a similar one) causing the poisoning. Regular algorithm monitoring and updating is required to ensure that it remains current, and research is needed to measure the algorithm's effectiveness in improving notification.

\section{International poisoning surveillance}

The algorithm is intended to promote compliance with international pesticide poisoning surveillance systems. SA is a signatory to the Rotterdam Convention, which requires countries to monitor severely hazardous pesticide formulations (SHPF): 'chemicals formulated for pesticidal use that produce severe health or environmental effects observable within a short period of time after single or multiple exposure, under conditions of use. ${ }^{11}$ In order for the convention to monitor and determine what constitutes an SHPF (e.g. street pesticide formulations), the Designated National Authority (DNA) in the country (the Department of Environmental Affairs in SA) must submit Pesticide Incident Report Forms (PIRFs) for poisonings from all pesticide classes. To comply with the Rotterdam Convention, the DoH replaced the old pesticide poisoning 'Epidemiological Investigation: Toxicology Form' with the PIRF in January 2011. ${ }^{12}$ Although the PIRF will aid in reporting poisonings associated with street pesticides, the current linear system of reporting may prevent these cases from reaching the DNA and Rotterdam Convention Secretariat.

\section{Conclusion}

The algorithm presented here has the potential to assist the notification of all pesticide poisonings, but particularly those from street pesticides. Accurate surveillance data are needed to illustrate this public health problem and associated burden. Although efforts are being made by the $\mathrm{DoH}$ and the Department of Agriculture to remove these pesticides from the streets, prosecution of informal vendors will have little effect on limiting access to the products as long as the problem of poverty-related pests is not simultaneously addressed. Healthcare professionals will have to continue recognising poisonings from these products.

Through application and broad implementation of the algorithm, statistics on the scope of the problem might foster national and international commitment to better controlled access to highly hazardous pesticides. Further research is needed on alternative mechanisms to improve the current notification system (e.g. mobile phone texting reporting to a central database) and health professionals' training in pesticide exposure recognition. Use of the algorithm for improved reporting is an important first step, especially to protect vulnerable children and draw attention to the importance of notifying all pesticide poisoning cases, and not just those involving OPs. Finally, it should be noted that the current poisoning notification surveillance system does not address a registry for chronic health effects resulting from pesticide exposures.

Acknowledgements. Funding was provided by the Danish International Development Agency (DANIDA) with support from the DoH and Medical Research Centre of South Africa. The author acknowledges contributions from members of the UCT Pesticide Reference Group, with special mention of Professor Leslie London and Roxanne Beauclair, who contributed considerably to development of the algorithm. This work was also supported by the UCT Vice Chancellor's award for Social Responsiveness to the author in 2010.

\footnotetext{
Department of Health (DoH). Disease Notification System. Pretoria: DoH, 20xx. http://www.doh.gov. za/show.php?id=2662\#list (accessed 6 January 2012).

London L, Ballie R. Challenges for improving surveillance for pesticide poisoning. Epidemiology 2001;30:564-570. [http://dx.doi.org/10.1093/ije/30.3.564]

Bertolote JM, Fleischman A, Eddleston M, Gunnel D. Death from pesticide poisoning: a global response. Br J Psychiatry 2006;189:201-203. [http://dx.doi.org/10.1192/bjp.bp.105.020834]

4. Rother H-A, London L. Occupational health concerns with pesticides in agriculture and beyond. 4. Rother H-A, London L. Occupational health conce
Continuing Medical Education 2009;27:506-508.

5. Balbus JM, Harvey CE, McCurdy LE. Educational needs assessment for pediatric health care providers 5. Balbus JM, Harvey CE, McCurdy LE. Educational needs assessment for pediatric health care provid
on pesticide toxicity. J Agromedicine 2006;11:27-38. [http://dx.doi.org/ 10.1300/J096v11n01_04]

on pesticide toxicity. J Agromedicine 2006;11:27-38. [http://dx.doi.org/ 10.1300/J096v11n01_04]
6. Rother H-A. Guideline for Preventing Child Pesticide Poisonings in South Africa. Cape Town: 6. Rother H-A. Guideline for Preventing Child Pesticide Poisonings in South Africa. Cape Town:
University of Cape Town, 2009. http://web.uct.ac.za/depts/oehru/dox/guidelines-managing-pesticidepoisoning.pdf (accessed 9 January 2012).

7. Reigart JR, Roberts JR, eds. Recognition and Management of Pesticide Poisoning, 5th ed.Washington: Environmental Protection Agency, 1999. http://npic.orst.edu/rmpp.htm (accessed 11 January 2012).

8. Rother H-A. Implications of South African women controlling poverty related pests with street pesticides. Women \& Environments International Magazine 2008;76/77:36-43.

9. Rother H-A. Falling through the regulatory cracks: street selling of pesticides and poisoning among urban youth in South Africa. Int J Occup Environ Health 2010;16:202-213. [http://dx.doi.org/10.117 9/107735210799160264]

10. Balme K, Roberts C, Glasstone M, Curling L, Rother HA, London L, Zar H, Mann M. Pesticide poisonings at a tertiary children's hospital in South Africa: an increasing problem. Clinical Toxicol 2010;48:928-934. [http://dx.doi.org/10.3109/15563650.2010.534482]

11. Rotterdam Convention. Severally Hazardous Pesticide Formulations (SHPF). http://www.pic.int/ Procedures/SeverelyHazardousPesticideFormulations/tabid/1191/language/en-US/Defaultaspx Procedures/SeverelyHazardousPesticideFormulations/tabid/1191/language/en-US/Default.aspx (accessed 6 January 2012).

12. Department of Health (DoH). Pesticide/Chemical Incident Report Form PIRF. Pretoria, DoH, 2011. http://www.doh.gov.za/docs/forms/2011/pesticide_form3.pdf (accessed 9 January 2012).
} 